\title{
Does forced voting result in political polarization?
}

\author{
Fernanda Leite Lopez de Leon ${ }^{1} \cdot{\text { Renata } \text { Rizzi }^{2}}^{2}$
}

Received: 31 July 2014/Accepted: 16 February 2016/Published online: 25 February 2016

(c) The Author(s) 2016. This article is published with open access at Springerlink.com

\begin{abstract}
This paper estimates the effects of the compulsory voting legislation on individuals' political orientations though a regression discontinuity framework. The identification comes from Brazil's dual voting system-voluntary and compulsory-whose exposure is determined based on citizen's date of birth. Using self-collected data, we find that compulsory voting legislation has sizable effects on individuals' political preferences, making them more likely to identify with a political party and to become extreme oriented.
\end{abstract}

Keywords Effects of voting - Compulsory voting $\cdot$ Political preferences · Brazil

JEL Classification D72 $\cdot$ D78

\section{Introduction}

Democracy lies in the heart of political economy (Downs 1957). Most democratic countries have a voluntary voting system; it is, however, debatable whether voting should be mandatory (Lijphart 1997). Compulsory voting is in place in 34 countries, and despite a recent growing literature, still little is known about the effects of this controversial voting system: whether it affects election outcomes and how it changes the electorate's political

Electronic supplementary material The online version of this article (doi:10.1007/s11127-016-0318-7) contains supplementary material, which is available to authorized users.

$\triangle$ Fernanda Leite Lopez de Leon

fernandallleon@gmail.com

Renata Rizzi

rizzirenata@gmail.com

1 Department of Economics, University of Kent, Canterbury CT1 2NX, UK

2 Department of Economics, Universidade de São Paulo, Molenberglaan, 17, 3080 Tervuren, Belgium 
views. In this paper, we address this last question and provide estimates of the causal effect of compulsory voting on individuals' degree of political polarization and political preferences.

The evidence is based on the Brazil's unique dual-voting system. Individuals between 16 and 18 years of age are entitled to vote, while those older than 18 are by law required to vote. ${ }^{1}$ We use data from a self-collected survey among young adults exposed to either system, conducted just after the 2010 presidential election in Brazil. We quantify the reduced form of the effect of voting participation by adopting a sharp regression discontinuity (RD) framework and looking at differences around the age of 18. Our estimates show how political preferences change in the transition from a voluntary to a compulsory voting system. We provide strong statistical evidence for these effects, thus contributing to the open debate among academics and the public regarding the consequences of a forced democracy (Krasa and Polborn 2009; Krishna and Morgan 2011; Borgers 2004; Ghosal and Lockwood 2009). More generally, our findings add to the understanding of the effects of voting participation on political preferences. The requirement of having to vote may affect citizens' level of political interest and, consequently, consumption of information and political preferences (Gerber et al. 2010). In this case, initiatives that encourage voting participation may in fact affect the citizenry's political orientations and contribute to polarization. In voting models that assume a cost-benefit calculus (Downs 1957; Coate and Conlin 2004; Degan 2006), political engagement and preferences are often assumed to be exogenous and determinants of electoral participation. In this paper, we test the opposite causal channel: whether these parameters respond to an exogenous change in voting turnout.

The identification of causal effects of turnout participation is challenging, giving that unobservables, such as intrinsic political interest, determine both voter turnout rates and other political outcomes. The literature adopts several approaches to identify these impacts. These approaches rely on field experiments that induce voting participation (León 2015; Gerber et al. 2010; Loewen et al. 2008). Other studies exploit changes in voting costs to identify the determinants and consequences of turnout (León 2015; Funk 2010). Gomez et al. (2007) and Hansford and Gomez (2010) examine variations in weather conditions on Election Day to establish a causal relationship between voting participation and election results at the US county level. They find that bad weather leads to lower turnout and helps Republicans to gain votes. Hansford and Gomez (2010) use an IV approach, explaining US presidential candidates' vote shares with turnout that is instrumented by Election Day rainfall. They predict that a $4 \%$ change in turnout leads to a change in the Democrat Party's vote share at the national level of around one percentage point. These large effects suggest that increases in voting participation can result in different election results. Godefroy and Henry (2013) use a similar strategy and data from French municipalities to uncover the relationship between turnout and implemented post-election policies. Hodler et al. (2015) examine the consequences of the introduction of voting via post in Switzerland, which resulted in increases in turnout. They find that this policy led to a change in electorate composition and to a reduction in government welfare expenditures.

This paper investigates the relationship between voting participation and political preferences at the individual level and in the context of the compulsory voting legislation. Similarly to this paper, León (2015) quantifies the effects of a lessening of penalties related to voting abstention in Peru, where voting is compulsory. In a field experiment, he

\footnotetext{
${ }^{1}$ Stronger sanctions are applied to those who fail to vote and are under compulsory voting. These will be explained in Sect. 2.
} 
provided information about the change in the penalties and found significantly lower voter turnouts as a result of that intervention. However, he did not detect changes in individuals' preferences for specific policies.

Another part of the literature exploits variation in individuals' voting age eligibility to identify the relationship between voting participation and political preferences. Mullainathan and Washington (2009) find that individuals eligible to vote (20-21 year olds) who are affiliated with the same party as the president evaluate him as two times better than non-eligible individuals (18-19 year olds) with the same party affiliation do 2 years after the election. Focusing on a field experiment, Gerber et al. (2010) find that unaffiliated registered voters strengthened their party identity after receiving the information that they need to register with a party to vote in a US primary election. Using an RD framework and exploring voting-age restrictions in the United States, Meredith (2009) finds that voting eligibility increases individuals' future chances of party registration in California. These studies illustrate only part of the voting effects. It is plausible that the opportunity to vote affects only those who are willing to participate in elections. The estimated voting effects reported in this paper are more compelling and unanticipated, as they are based on exposure to a compulsory voting system, affecting those who choose to abstain during elections.

Our estimated effects of the transition from a voluntary to a compulsory voting system are also important, because they contribute to the literature on the evaluation of voting systems. A large number body of studies is focused on predicting election outcomes under full turnout, ${ }^{2}$ arguably the most important consequence of the compulsory voting legislation. Citrin et al. (2003) and Brunell and DiNardo (2004) predict the ballot choices of non-voters based on the choice of voters with similar demographics, and they then forecast election results under full participation. A key problem in extrapolating these results, for understanding the impacts of compulsory voting legislation, is that none of the literature considers a potential change in preferences owing to compulsory voting. The data used in this paper are ideal for shedding light on this issue. They also provide empirical validation for a key assumption-that ideological preferences are fixed-in voting models that investigate welfare implications of voting systems (Krasa and Polborn 2009; Krishna and Morgan 2011; Borgers 2004; Ghosal and Lockwood 2009).,

\footnotetext{
2 The literature has mixed results. While early studies conclude that changes in turnout would not cause significant changes in election outcomes (Citrin et al. 2003; Brunell and DiNardo 2004; Highton and Wolfinger 2001), others predict important changes (Martinez and Gill 2005; Gomez et al. 2007; Hansford and Gomez 2010).

3 The conclusion in this literature is also mixed. Krasa and Polborn (2009) assume an environment wherein voters do not face uncertainty regarding candidates' characteristics, only regarding their voting costs, and decide their votes based on ideology. They show that mandatory voting outperforms voluntary voting if the expected absolute sizes of the candidates' supporting groups are sufficiently different. In contrast, Krishna and Morgan (2011) add competence as an extra dimension of politicians' characteristics. They assume that voters choose between two candidates based on ideology and competence and show that, with voluntary and costly voting, turnout adjusts endogenously (as voters on different ideological sides perceive different values in electing candidates fielded by their parties), so the most competent candidate is always elected. In a compulsory system, on the other hand, elections are decided purely on an ideological basis and, differently from voluntary voting, welfare is not always maximized.

${ }^{4}$ Other literature, which also assumes fixed preferences, provides a link between voting turnout and political rents (Aldashev 2015; Hodler et al. 2015). Aldashev (2015) develops a probabilistic-voting model that finds that ideological neutral citizens are less likely to vote. Under compulsory voting, they are brought into the electorate, intensifying electoral competition and driving down political rents.
} 
We find that, when passing from a voluntary to a compulsory voting system, individuals become 2-4 percentage points (pps) more likely to self-declare themselves as extremely left-wing oriented and become 5-8 pps more likely to align with a specific party (PSDBPartido da Social Democracia Brasileira). We do not find evidence that these effects are related to individuals' information gains or increases in their senses of political civism. Considering that our identification strategy relies on a comparison of individuals who are almost identical in age (and presumably indistinguishable by politicians), it is also unlikely that the results are driven by political parties targeting young voters in their campaigns.

In addition, we find that individuals change their minds about the characteristics they find to be important in an ideal candidate. Perhaps surprisingly, "charisma" becomes at least twice more likely to be cited as the most important characteristic in an ideal politician with the transition from voluntary to a compulsory voting system. This suggests that changes in political orientations might to some extent be explained by internal thought processes triggered by the obligation to vote. Individuals might think more about the election and re-evaluate their assessments of candidates' characteristics, political parties and their stands on policy issues.

This paper proceeds as follows. In Sect. 2, we provide an overview of Brazilian politics. In Sect. 3, we explain the data and the method, and we present the results in Sect. 4. We discuss and conclude in Sect. 5.

\section{Brazil's political institutions}

As mentioned, Brazil has a dual voting system. Individuals between 16 and 18 years old (or older than 70 years) are entitled to vote, while those older than 18 (and younger than 70 years) are required to vote by law. All voters must register and registration is compulsory for Brazilians between 18 and 70 years of age. In election years, citizens planning to vote are required to register at least 150 days before Election Day. No fee is charged and individuals are granted an authorized absence from work of up to 2 days in order to register. When individuals who are required to vote fail to do so and fail to provide justification for their abstention to the electoral authority, they must pay a small fine. ${ }^{5}$

Stronger sanctions are applied to those who fail to vote in three consecutive elections. They are not allowed to issue or renew their passports or national identity cards; they also become ineligible for public education, public jobs, cash transfer programs, and credit from state-owned financial institutions.

Mandatory voting was introduced in Brazil in 1932, when the country's first Electoral Code was created following the Revolution of $1930 .{ }^{6}$ In 1964, a coup d'etat initiated a period of 21 years of military rule in the country, during which the regime controlled the electoral process according to its interests through a series of institutional acts, constitutional amendments, laws, and decrees. Direct elections for president, governors, and

\footnotetext{
5 The fine is R\$ 3.51 or approximately 1 USD, according to 2015 values.

${ }^{6}$ One of the principles of the Revolution was the normalization of the electoral system. One of the first acts of the provisional government was the creation of a commission to reform the electoral legislation. Advances in the electoral legislation were subsequently included in the Constitution of 1934; in 1937, however, a new constitution was imposed by President Vargas to extinguish the Electoral Justice, thus dissolving the existing political parties and suspending direct elections. The deposition of President Vargas in 1945 marked the redemocratization of the country, with the reestablishment of the Electoral Justice System and the restoration of rights suppressed in 1937. At that time, voting once again became mandatory for all citizens over 18, except for military officers and citizens over 65 years (illiterates were not allowed to register).
} 
Table 12010 Chamber of deputies election results

\begin{tabular}{|c|c|c|c|c|c|}
\hline Ideology & Party & Seats & Ideology & Party & Seats \\
\hline Left & $\begin{array}{l}\text { Partido dos Trabalhadores } \\
\text { (PT) }\end{array}$ & 88 & Left & $\begin{array}{l}\text { Partido da Mobilização } \\
\text { Nacional (PMN) }\end{array}$ & 4 \\
\hline Center & $\begin{array}{l}\text { Partido do Movimento } \\
\text { Democrático Brasileiro } \\
\text { (PMDB) }\end{array}$ & 78 & Center & $\begin{array}{l}\text { Partido Trabalhista do } \\
\text { Brasil (PT do B) }\end{array}$ & 3 \\
\hline Center-left & $\begin{array}{l}\text { Partido da Social Democracia } \\
\text { Brasileira (PSDB) }\end{array}$ & 54 & Extreme left & $\begin{array}{l}\text { Partido Socialismo e } \\
\text { Liberdade (PSOL) }\end{array}$ & 3 \\
\hline Center-right & Democratas (DEM) & 43 & Center & $\begin{array}{l}\text { Partido Humanista da } \\
\text { Solidariedade (PHS) }\end{array}$ & 2 \\
\hline Center & Partido da República (PR) & 42 & Center & $\begin{array}{l}\text { Partido Republicano } \\
\text { Progressista (PRP) }\end{array}$ & 2 \\
\hline Right & Partido Progressista (PP) & 41 & Right & $\begin{array}{l}\text { Partido Renovador } \\
\text { Trabalhista Brasileiro } \\
\text { (PRTB) }\end{array}$ & 2 \\
\hline Left & $\begin{array}{l}\text { Partido Socialista Brasileiro } \\
\text { (PSB) }\end{array}$ & 34 & Center & $\begin{array}{l}\text { Partido Social Liberal } \\
\text { (PSL) }\end{array}$ & 1 \\
\hline Center-left & $\begin{array}{l}\text { Partido Democrático } \\
\text { Trabalhista (PDT) }\end{array}$ & 28 & Center-right & $\begin{array}{l}\text { Partido Trabalhista Cristão } \\
\text { (PTC) }\end{array}$ & 1 \\
\hline Center & $\begin{array}{l}\text { Partido Trabalhista Brasileiro } \\
\text { (PTB) }\end{array}$ & 21 & Center & $\begin{array}{l}\text { Partido Trabalhista } \\
\text { Nacional (PTN) }\end{array}$ & 0 \\
\hline Center-right & Partido Social Cristão (PSC) & 17 & Center-right & $\begin{array}{l}\text { Partido Social Democrata } \\
\text { Cristão (PSDC) }\end{array}$ & 0 \\
\hline Center & Partido Verde (PV) & 15 & Extreme left & $\begin{array}{l}\text { Partido Socialista dos } \\
\text { Trabalhadores Unificado }\end{array}$ & 0 \\
\hline Left & $\begin{array}{l}\text { Partido Comunista do Brasil } \\
\quad(\mathrm{PC} \text { do } \mathrm{B})\end{array}$ & 15 & Extreme left & $\begin{array}{l}\text { Partido da Causa Operária } \\
\text { (PCO) }\end{array}$ & 0 \\
\hline Center-left & $\begin{array}{l}\text { Partido Popular Socialista } \\
\quad \text { (PPS) }\end{array}$ & 12 & Extreme left & $\begin{array}{r}\text { Partido Comunista } \\
\text { Brasileiro (PCB) }\end{array}$ & 0 \\
\hline Center-right & $\begin{array}{l}\text { Partido Republicano Brasileiro } \\
\text { (PRB) }\end{array}$ & 7 & & & \\
\hline
\end{tabular}

Sources TSE and Wikipedia

mayors of strategic municipalities were suspended, and existing political parties were again banned. A new transition to democracy began in 1985, when a constitutional amendment re-established direct elections in the country, reinstating the right to vote for those older than 18 and the literacy test for voting was abolished. In 1988, the current Brazilian Constitution was promulgated, adopting compulsory voting for literate individuals between 18 and 69 years of age and voluntary voting for the remaining citizens (Tribunal Superior Eleitoral-TSE). ${ }^{7}$

The 1988 constitution also stipulated that the Federative Republic of Brazil is a legal democratic state. Both the federal government and the governments of Brazil's 26 states consist of executive, legislative, and judicial branches. Executive power is wielded by the President of the Republic. The National Congress, which consists of the Chamber of Deputies and the Federal Senate, is in charge of the legislative power. Brazil has a multiparty system. In 2013, the total number of parties was 32. However, most of the elected politicians are affiliated with fewer than ten of them. Table 1 shows the number of seats

7 www.tse.jus.br/internet/ingles/historia_eleicoes/eleicoes_brasil.htm. 
held by members of the Chamber of Deputies, presented by party and their ideological positioning, as a result of the 2010 election. ${ }^{8,9}$

Most of the seats were held by parties in the center $(63.5 \%)$, followed by the left $(28 \%)$ and the right $(8.4 \%)$. There are four main parties at the national level: the left Partido dos Trabalhadores (PT), center-oriented Partido do Movimento Democratico Brasileiro (PMDB), center-left Partido da Social Democracia Brasileira (PSDB), and the center-right Democratas (DEM). In the 2010 election, the three main presidential candidates, Dilma Rousseff, Jose Serra, and Marina Silva, were affiliated respectively with the PT, PSDB, and PV parties. The PV party is the less representative among them (as shown in Table 1). It is a party whose main agenda is based on environmental issues, and it is viewed as center-left.

\section{Data and method}

The data come from a self-collected survey of 5559 students in 109 classrooms in eight schools in the city of São Paulo, Brazil. This is the same data used in the analysis by Leon and Rizzi (2014). Participants are senior high school students (13.1\%), college freshmen $(20.3 \%)$, and students in the transition between high school and college $(66.6 \%)$. On average, $67.6 \%$ have a mother with a college degree, $57 \%$ are female, and $76 \%$ are white. This group is a non-random sample of Brazil's younger population and, hence, some selection sample bias might be present, although in aggregate, the voting turnout participation by the age group in our sample is very similar to the Brazilian population (Leon and Rizzi 2014).

Participants were not informed about the specific purpose of the questionnaires, except for its title, "Young Adults' Political Behavior", and that the survey was associated with the Universidade de São Paulo. The survey (October 4-7) was conducted a few days after the 2010 Brazilian presidential election (October 3, 2010). The timing of the data collection is appropriate, as people are likely to think about politics and evaluate their own political views near an election. Using these data and an RD approach, as reported in Leon and Rizzi, we find that exposure to the compulsory voting system resulted in a large increase in individuals' voting participation, of between 34 and $40 \%$.

In this article, we ask whether changes in the degree of political polarization and voter preferences are also observed, focusing on the following outcomes. First, we created an indicator for those who answered positively to the survey question: "Do you have a preference for a political party?" Second, we recorded whether a respondent self-declared as being center-oriented (as opposed to moderately or extremely right- or left-wing). Then, we created a polarization index to account for the different degrees of polarization. This variable assumes a value of 0 if the respondent declared being center-oriented, 1 if the respondent declared as moderate, and 2 if the respondent declared to be extreme. To understand whether "directional" changes in ideological positioning exist, we constructed a five-point right-wing index coded from -2 (if the respondent declared to be extreme left-

\footnotetext{
${ }^{8}$ In Table 1 and as discussed in the text, we show the party ideological classification as described in the Wikipedia page of political parties. Because Wikipedia pages are constantly monitored by parties, this information is most likely to be reliable. There is a strong resemblance between this measure and the party ideological classification made by Brazilian political scientists (Carreirao 2006).

${ }^{9}$ Representatives sitting in the Chamber of Deputies and the State Assemblies are elected by direct ballot in an open-list proportional system.
} 
wing), -1 (moderate left-wing), 0 (center-oriented), +1 (moderate right-wing), and +2 (right-wing). Based on these previous questions, we also created indicators for whether an individual declared to be extreme-oriented to the left or to the right as well as their specific party preference. We focused on the preference for three political parties, PSDB, PT, and $\mathrm{PV}$, because $87.5 \%$ of participants with a party preference were aligned with one of them. More specifically, $55 \%$ of them prefer the PSDB, $12.8 \%$ prefer the PT party, and $19.7 \%$ prefer the PV party. The remaining respondents declared preference for the PSOL $(7.9 \%)$, PMDB (1\%), DEM (0.2 \%), and other various parties. We abstract from those last cases because of small numbers, making it difficult to identify any effect.

We focused on a sample of 3027 students who were between 16.75 and 19.25 years old on Election Day 2010 (sufficiently close to the cutoff) and who answered the political preference question. Table 2 describes the outcomes by voting participation status.

Voters are more polarized (less likely to be center-oriented and more likely to prefer a political party) than non-voters. They are also more likely to assert preferences for the PSDB and PT parties. These differences can cause, be caused by voting, or both.

To overcome this endogeneity issue and estimate the causal effects of electoral participation, we use a regression discontinuity framework. The Brazilian compulsory voting legislation increases the cost of abstention. It provides an exogenous shift in individuals' likelihood of voting at the age of 18. Assuming no other change at the cutoff age (as will be discussed below), a discontinuity in political preferences revealed by the comparison of individuals on either side of the 18-year-old threshold should be consequence of the change in the voting system - from voluntary to compulsory - and its induced increase in voting participation. The estimates for $\delta$ in Eq. 1 (below) are most likely to be causal because the probability an individual falls below or above the 18-year threshold and, thus, exposure to the treatment (of the compulsory voting legislation), is determined as if it was generated by a random process. Hence, around the cutoff, the exposure to the compulsory voting legislation is independent of unobservables determining both turnout participation and political behavior.

The key condition for identification in RD regressions is that no other relevant changes occur at the cutoff age. We argued this to be the case in Leon and Rizzi (2014). We followed

Table 2 Descriptive by voting status in the 2010 election

\begin{tabular}{llllll}
\hline Outcomes & $\begin{array}{l}\text { All } \\
(1)\end{array}$ & $\mathrm{N}$ & $\begin{array}{l}\text { Voter } \\
(2)\end{array}$ & $\begin{array}{l}\text { Non-voter } \\
(3)\end{array}$ & $(2)-(3)$ \\
\hline Center-oriented & $0.5362(0.498)$ & 2952 & $0.4924(0.500)$ & $0.6532(0.476)$ & $-0.1608^{* *}$ \\
Polarization index & $0.5105(0.586)$ & 2952 & $0.5568(0.588)$ & $0.3846(0.559)$ & $0.1722^{* *}$ \\
Prefers a political party & $0.3369(0.473)$ & 3027 & $0.3827(0.486)$ & $0.2184(0.413)$ & $0.1643^{* *}$ \\
Ideology index & $0.0118(0.777)$ & 2952 & $0.0183(0.8096)$ & $-0.0012(0.678)$ & 0.0195 \\
Extreme left-wing & $0.0294(0.169)$ & 2952 & $0.0314(0.175)$ & $0.0219(0.146)$ & 0.0095 \\
Extreme right-right & $0.0172(0.130)$ & 2952 & $0.0178(0.1324)$ & $0.0158(0.125)$ & 0.002 \\
Prefers PSDB party & $0.185(0.388)$ & 3027 & $0.2146(0.411)$ & $0.1098(0.313)$ & $0.1048^{* *}$ \\
Prefers PT party & $0.0436(0.204)$ & 3027 & $0.048(0.2138)$ & $0.0327(0.178)$ & $0.0153^{*}$ \\
Prefers PV party & $0.0664(0.249)$ & 3027 & $0.0706(0.256)$ & $0.0561(0.230)$ & 0.0145 \\
\hline
\end{tabular}

Standard deviations are in brackets

* Significant at the $10 \%$ level

** Significant at the $5 \%$ level 
the guidelines of Lee and Lemieux (2010) and tested for possible confounding effects. We estimated Eq. (1) below using several covariates, such as demographic and family characteristics, as endogenous variables to test for other "shocks" at the age of 18 . We did not detect statistically significant changes for most variables. Another potential threat lies in the fact that effects are identified at the age of 18 , when youngsters reach the age of legal majority. We obviously accept that new opportunities and responsibilities which become available might change individuals, but this happens gradually and not abruptly at the 18th birthday. We tested whether students changed their behavior regarding their propensity to apply for college admission exams or to respond seriously to the survey at the threshold. In line with our expectations, none of these behavioral changes materialized. These results are reported in Leon and Rizzi (2014) and in Appendix Table 5 for the sample used in this paper (that further focuses on individuals who answered the political question).

We follow the guidelines of Lee and Lemieux (2010), and we estimate Eq. 1 to quantify the main effects:

$$
y_{i}=\alpha+\beta X_{i}+\mathrm{M}(\text { age })+\delta(\text { age } \geqq 18)+\theta+u_{i}
$$

where $y_{-} i$ represents the outcome of individual $i$; $X \_i$ contains a number of covariates (indicators for gender, race, and mother's education, as well as for whether the individual has voted before), $\theta$ are school fixed effects, $\delta$ (age $\geqq 18$ ) is a dummy indicating whether the student had turned 18 by the 2010 election, M(age) is a polynomial in age (measured by the distance in days to the 18th birthday) that is flexible on each side of the cutoff. It is supposed to better control for age effects within the sample and to estimate the effect of interest robustly. The error term is represented by $u_{-} i$.

\section{Results}

\subsection{Effects of compulsory voting on party and ideological preferences}

Table 3 presents the OLS estimates for the $\delta$ coefficient, which represents the effect of the compulsory voting legislation. Each entry in columns 2-4 represents results from a separate regression. Following Lee and Lemieux (2010), we present the results for several age polynomials and for the optimal age polynomial according to the Akaike criterion.

In the first and second rows, we report the results using as a dependent variable an indicator for whether the individual self-declared to be center-oriented and for the polarization index, respectively. The estimates do not reveal any discontinuity around the 18 -year old threshold. The estimated coefficients for any of the tested specifications are not statistically significant ( $p$ value $>25 \%$ ). In the third row, we report the results for political party preference and find some evidence of such an effect. The coefficient is statistically significant at the $5 \%$ level, but only for the specification controlling for a quadratic age polynomial. In this case, the coefficient indicates an increase in this likelihood of 9.83 percentage points (or $34 \%$ ) at the 18-year old threshold.

In rows (4)-(9), we look for whether exposure to compulsory voting leads to directional effects on ideological positioning. We find evidence that it does, as shown in Table 3, rows 4, 5 and 7. The estimates in row 5 indicate that individuals become significantly more likely to self-declare to be extreme left-wing (between 2 and 4 percentage points). Row 7 shows that compulsory voting leads to an increase in the likelihood of asserting a preference for the PSDB party by 5-8.6 percentage points. In the results not shown in this 


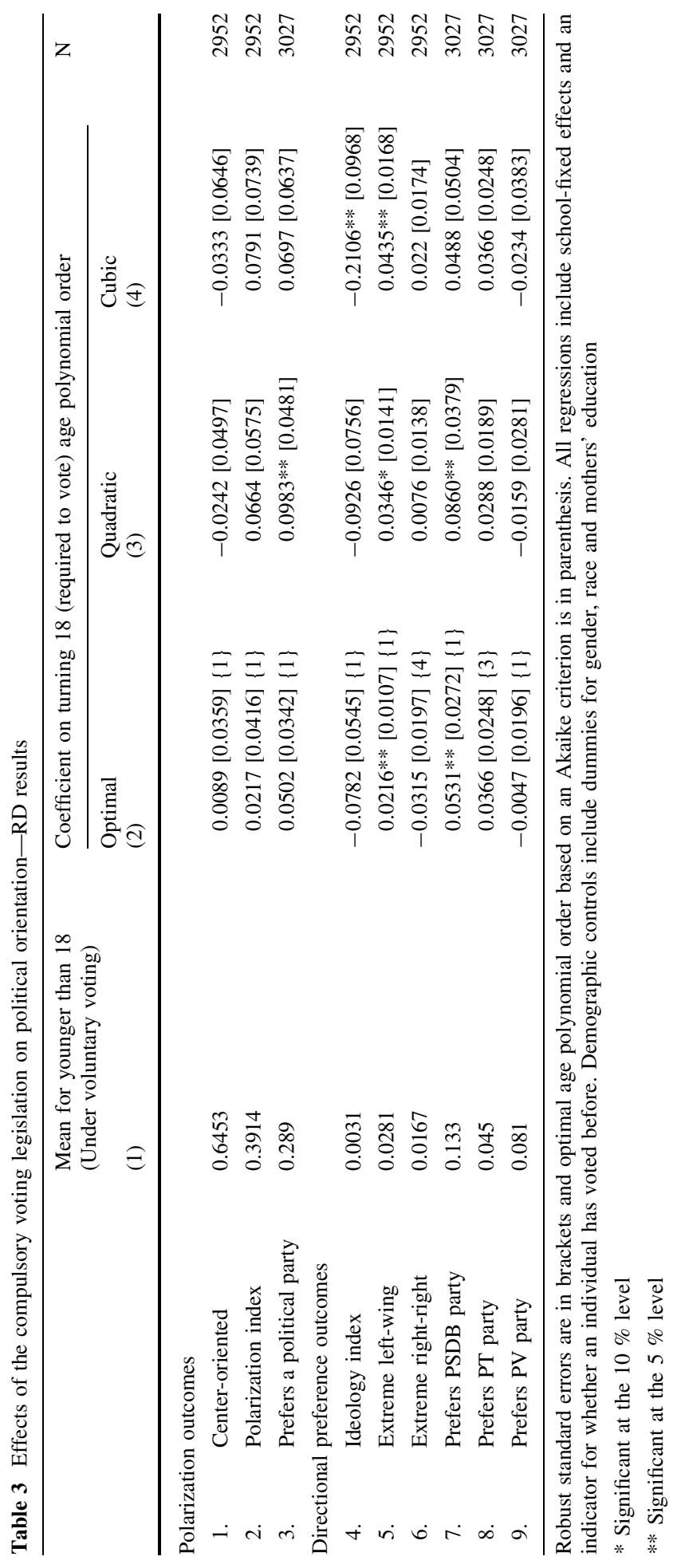


paper, we find that these directional results (in rows 4, 5 and 7) are also robust to local linear regressions using different bandwidths. The findings are supported by graphical analysis, presented in the supplementary material. The figures clearly indicate discontinuities in political preferences when individuals move from voluntary to compulsory voting.

In summary, the findings in Table 3 indicate changes in the population's political positioning resulting from exposure to compulsory voting. These results are in line with those in Hansford and Gomez (2010) and suggest that the adoption of this voting legislation would favor left-wing parties. These results are not especially driven by lowerincome individuals, who are also less likely to vote. In Appendix Table 6, we show the results from Table 3 categorized by income.

With the estimates from Eq. 1, we can conduct counterfactuals to quantify how the PSDB party would be affected if the transition from voluntary to compulsory voting was to be delayed and occur at the age of 19 (after individuals reach majority) instead of at 18 . According to our estimates, the predicted proportion of individuals that prefer the PSDB party among youngsters between 17 and 20 years old (comprising $7.6 \%$ of the total voting population according to the TSE) is $18.5 \%$. If the compulsory voting age were to be moved to 19 , this support would fall to $16.3 \%{ }^{10}$

\subsection{Effects of compulsory voting on political preferences and information acquisition}

Next, we check whether the exposure to the compulsory voting legislation affects other measures of political engagement and information acquisition as likely explanations for the impacts reported in Table 3. The obligation to vote might makes people more likely to become engaged in politics, moving them toward a more polarized position. Having to vote may trigger senses of responsibility and involvement in politics. We asked participants to rate how aligned they feel, on a scale of zero (less aligned) to ten (most aligned), with the following statement: "I feel good while voting because I am exerting my civic duty." In Table 4, row 1, we present the estimates of $\delta$ when using this self-assessment scale as a dependent variable. We do not detect an effect of compulsory voting in determining this variable.

Another possibility is that individuals actively consume more information because they are required to vote. Assume that citizens vote for expressive reasons and that they perceive a cost of making a voting mistake (Matsusaka 1995; Degan 2006). They may become more likely to consume political information under compulsory voting $(\mathrm{CV})$ than in a voluntary voting system because, under $\mathrm{CV}$, citizens can no longer abstain, remain uninformed, and avoid the cost of making a voting mistake. ${ }^{11}$ The polarization and change in political preferences may be the result of such a gain in information. We tested for this possible channel by checking whether the participants' number of mistakes on the political quiz regarding each of the main three presidential candidates-Rousseff (PT), Serra (PSDB), and Silva (PT)—changes in a discontinuous manner at the age of 18 . The results

\footnotetext{
10 The estimates use the sample of individuals between 16.75 and 19.2 years old and the empirically optimal age polynomial. To calculate the predicted rates, we use the sample of individuals between 17 and 20 years old.

11 In their models, the perceived cost of making a voting mistake prevent individuals from marking their ballots randomly. Citizens behave as if voting is an ethical issue, in the sense that they decide between: voting well or abstaining, as also argued in Brennan's work "The Ethics of Voting".
} 


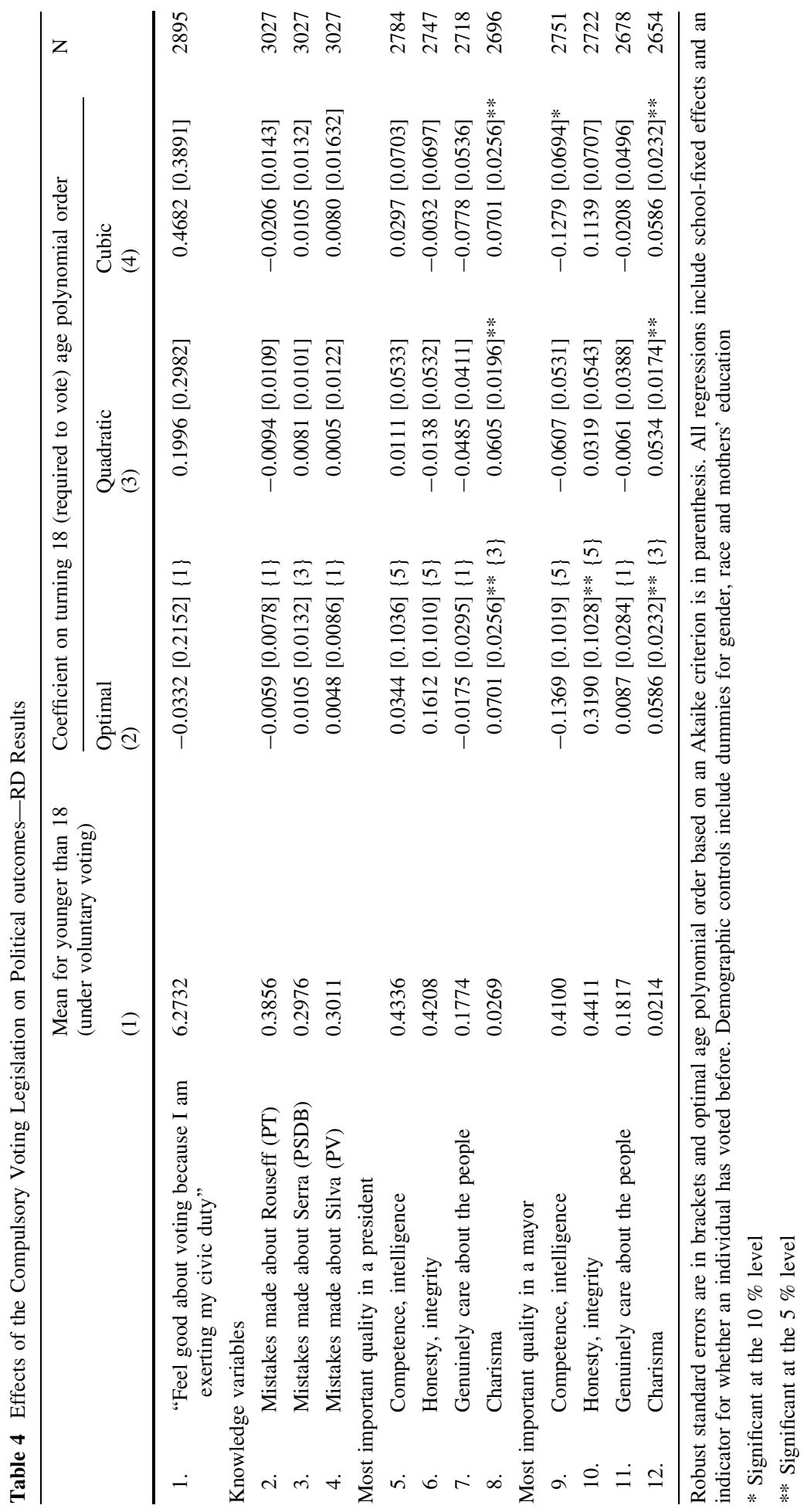


are reported in Table 4, rows (2)-(4). Again, we do not find any statistically significant results for any specification. In Leon and Rizzi (2014), we report the results for a number of other knowledge and consumption of information variables, and, as in Table 4, rows (2)-(4), we find no statistically significant result.

Despite these findings, it might be that individuals reflect more about politics given the information they have on hand. This is not directly testable (we do not have information on how much time and effort participants allocate to thinking about politics), but we examine whether individuals change the way they evaluate politicians' characteristics. We asked participants to rank several qualities of an ideal politician (president and mayor) among four alternatives. To understand whether and how these preferences change, we create indicators for whether the respondent chose a specific characteristic as the most important one. As shown in Table 4, column 1, rows (5)-(8), the most cited characteristics of an ideal president among voters under a voluntary voting system are (i) competence and intelligence $(43.4 \%)$, (ii) honesty and integrity $(42.1 \%)$, (iii) genuine care about the people $(17.8 \%)$, and (iv) charisma $(2.7 \%) .^{12}$

Table 4, columns (2)-(4), show results from estimates of Eq. (1), using each of these dummies as dependent variables. We find that charisma becomes 7 percentage points more likely to be cited as the most important characteristic in an ideal president (row 8) when citizens are under compulsory voting. The size of this effect is large. It is cited three times more often as the most important quality in a president among compulsory voters $(9.7 \%)$ than among voluntary voters $(2.7 \%)$. In rows (9)-(12), we find a similar pattern for the impact of compulsory voting on the most important characteristic in a mayor. Individuals become 5.9 percentage points more likely to mention charisma as the most important characteristic in an ideal mayor. We find some weak evidence of the effect of compulsory voting for other characteristics. For some specifications, we find that honesty and integrity becomes more likely to cited (row 10, column 2), while competence and intelligence become less likely to be cited as the most important characteristic (row 9, column 4).

\section{Discussion and conclusion}

In this paper, we document the short-term effects of compulsory voting in determining individuals' political positioning. We explore a quasi-experimental design that exogenously assigns people to different voting systems: voluntary and compulsory. Similar to this paper, Meredith (2009) uses an RD approach comparing future political party alignments for individuals who are almost eligible (are almost 18 years old) with those that are just eligible to vote in the United States. Meredith (2009) finds that 2000-eligible voters became 2 percentage points more likely to be registered with a party and to be registered as a Democrat. We find that, upon being exposed to the compulsory voting legislation, individuals become 2-4 percentage points more likely to self-declare an extreme-left orientation and 5-8 percentage points more likely to express a preference for the PSDB party in the 2010 Brazilian election.

A plausible explanation for our findings is that this is a consequence of party strategic behavior. For example, parties might be targeting coming-of-age voters with political campaigns (Huber and Arceneaux 2007). We are unaware of such campaigns, and national polls (e.g., IBOPE—Instituto Brasileiro de Opinião Pública e Estatística, 2010) do not reveal differences in preferences across relevant age groups. In addition, our identification

12 They total more than $100 \%$ because some participants ranked multiple characteristics in the first place. 
strategy most likely rules out this explanation as a possible reason for our findings. Our results rely on the comparison of individuals who are almost 18 years old with those who are just 18 by the time of the election. They are presumably identical, on average, regarding their policy preferences and indistinguishable by parties.

We tested whether the change in political preferences is a consequence of individuals' gaining information or increasing their senses of civic duty, triggered by the requirement of having to vote. The new information acquired could lead to an update about which party/ side best represents individuals' interests and to an explanation for a change in preferences. We do not find supportive evidence for this hypothesis. Alternatively, it is also possible that the obligation to vote makes individuals pay closer attention to politics and to reflect more on what they are looking for in candidates, despite not consuming more political information. We find that, in addition to changing their preferences toward political parties and ideological positions, individuals update their evaluations of the characteristics they find to be more important in an ideal candidate. This supports the explanation that the compulsory voting legislation makes citizens think more about politics. This may also explain the observed changes in their political preferences.

Remarkably, we find robust evidence that charisma is more likely to be cited as the most important characteristic in an ideal candidate than other traits that are more commonly associated with higher-quality politicians, such as competence, honesty, and genuine care about the people. This result resonates with the discussion of welfare implications of high voter turnouts. Hodler et al. (2015) show that the implementation of postal voting in Switzerland was associated with changes in electorate characteristics and less spending on welfare programs by elected politicians. They interpret this finding in the context of a voting model in which candidates' policy stances respond to the composition of the electorate. Initiatives that lower voting costs (like postal voting or compulsory voting) lead to an increase in the proportion of impressionable voters whose ballot choices are more sensitive to campaigns (and charismatic candidates) than to policy platforms. As a consequence, candidates propose parochial policies that might not be optimal for all citizens in society. In this paper, we find that charisma becomes a more important characteristic in an ideal politician, suggesting that (at least) the young electorate is more impressionable under compulsory rather than under voluntary voting. It is possible that this effect is reinforced by the "supply of politicians", that itself reacts to the preferences of the electorate. Recently, many celebrities have run for election and some of them have been elected with a considerable number of votes. ${ }^{13}$ As discussed in the media (Frota 2014), although these public figures from the entertainment business are viewed with skepticism by most of the population, they are becoming more common in the political arena. With the goal of gaining seats in the national legislature, political parties approach both experienced politicians and celebrities to run for office, so as to ensure a larger number of votes in the next congress.

Worth mentioning is the fact that this research has some important limitations in terms of its external validity. The effects are quantified among young citizens who are still developing their political preferences (Prior 2010; Sears and Funk 2010; Franklin 2004). They might be more susceptible to the exposure of the compulsory voting legislation than the median-age voter in Brazil. In this sense, the results reported in this paper might provide an upper bound for the effect of compulsory voting in determining individuals'

\footnotetext{
13 Among those are the former soccer players Romario (elected with 4,683,963 votes) and Bebeto (elected with 61,082 votes), and television celebrities Celso Russomanno (elected with 1,524,361 votes) and "Tiririca" (elected with 1,016,796 votes).
} 
degree of polarization. For example, León (2015) does not find such effect. ${ }^{14}$ One could expect smaller effects if the voting age requirement was set later in life, such as 30 years old instead of 18. Likewise, if the compulsory voting system was to be newly introduced in another country, it might cause smaller immediate effects.

The effects quantified in this paper are only a short-term facet of the consequences of compulsory voting. Investigating the long-term, permanent effects of compulsory voting and the precise mechanisms of influence partisanship is important and awaits future research.

Acknowledgments We thank William Shughart II and anonymous referees for constructive suggestions. We are also grateful to Stephen Coate, Naercio Menezes and Jeffrey Prince for helpful comments. We are very gratful to Ernesto Birner and many other teachers at Anglo Vestibulares, Escola E. Professor Ascendino Reis, Escola E. Rui Bloem, Escola E. Professor Leopoldo Santana and Universidade de São Paulo for their support and help in the application of our survey. We thank Insper Institute for their financial support.

Open Access This article is distributed under the terms of the Creative Commons Attribution 4.0 International License (http://creativecommons.org/licenses/by/4.0/), which permits unrestricted use, distribution, and reproduction in any medium, provided you give appropriate credit to the original author(s) and the source, provide a link to the Creative Commons license, and indicate if changes were made.

\section{Appendix}

See Tables 5 and 6.

Table 5 Estimated discontinuities in pre-determined characterstics

\begin{tabular}{llll}
\hline & {$[1]$} & {$[2]$} & $\mathrm{N}$ \\
\hline Dependent variable & & & \\
White & $0.0114[0.0303]$ & $0.0182[0.0431]$ & 3027 \\
Female & $-0.0851[0.0359]^{* *}$ & $-0.0714[0.0498]$ & 3027 \\
Mother has college education & $0.0419[0.0297]$ & $0.0475[0.0412]$ & 3027 \\
Lives with parent(s) & $-0.0330[0.0231]$ & $-0.0009[0.0328]$ & 2785 \\
Works & $-0.0256[0.0216]$ & $-0.0431[0.0307]$ & 2766 \\
Responded seriously to the survey & $0.0221[0.0188]$ & $0.0173[0.0251]$ & 3001 \\
Plans to apply to College & $-0.0084[0.0227]$ & $0.0096[0.0326]$ & 2625 \\
Frequency of church attendance (times per month) & $-0.2259[0.2379]$ & $-0.2563[0.3511]$ & 2712 \\
Mother has a party preference & $-0.0124[0.0412]$ & $0.0338[0.0574]$ & 2503 \\
Age polynomial controls & Linear & Quadratic & \\
\hline
\end{tabular}

The sample includes individuals between 16.75 and 19.25 years old. Entries represent OLS regression results including age polynomial controls fully interacted with a dummy for age 18 or older, and school fixed effects

Huber White standard errors are in brackets

** Significant at the $5 \%$ level

\footnotetext{
14 In addition to the reason above, the current paper and León (2015) differ in the nature of the intervention studied. He looks at the effect of removing some of the voting costs in Peru where voting is compulsory. Hence that intervention is likely to have smaller impacts than the one found in this paper.
} 


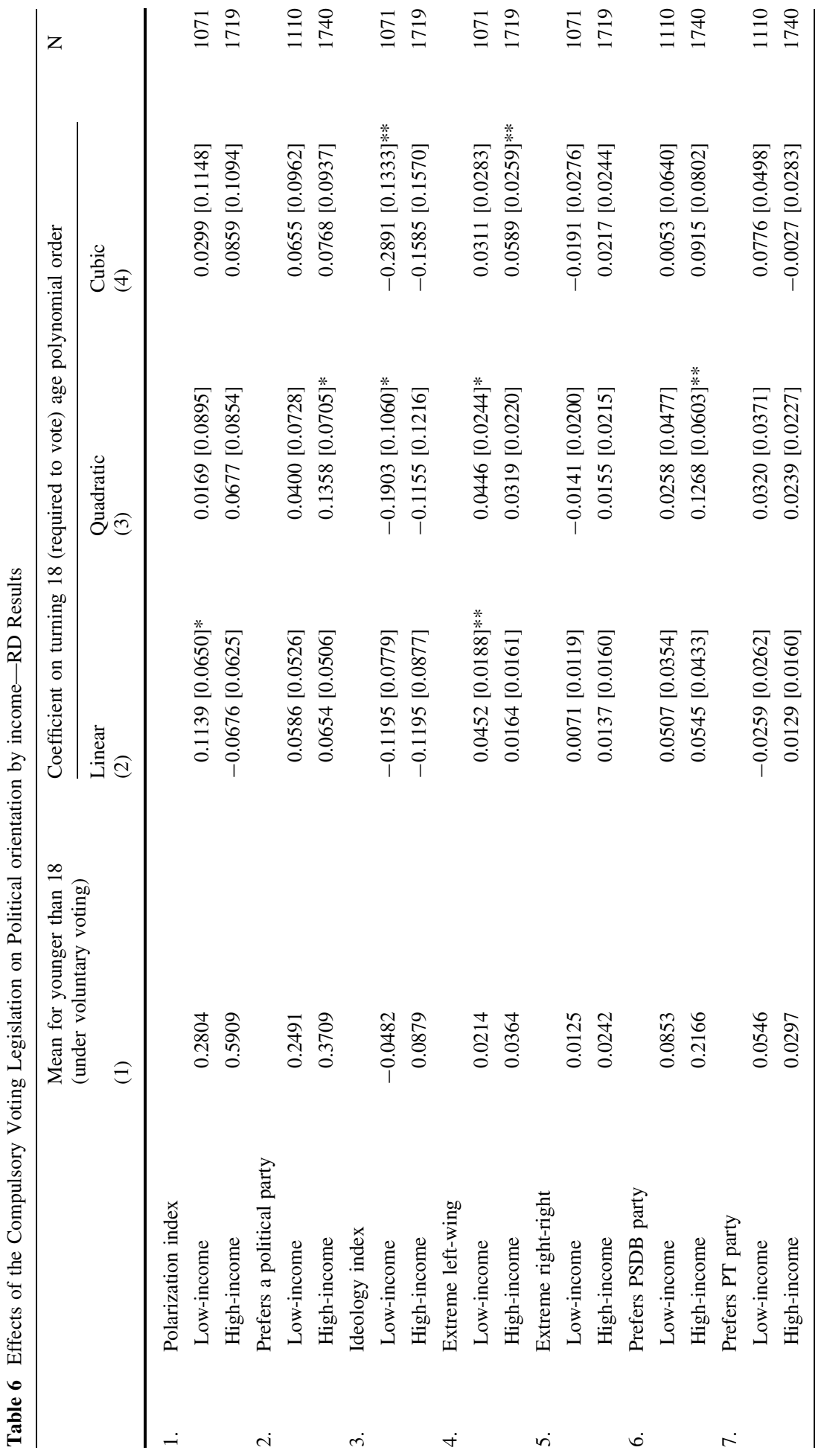




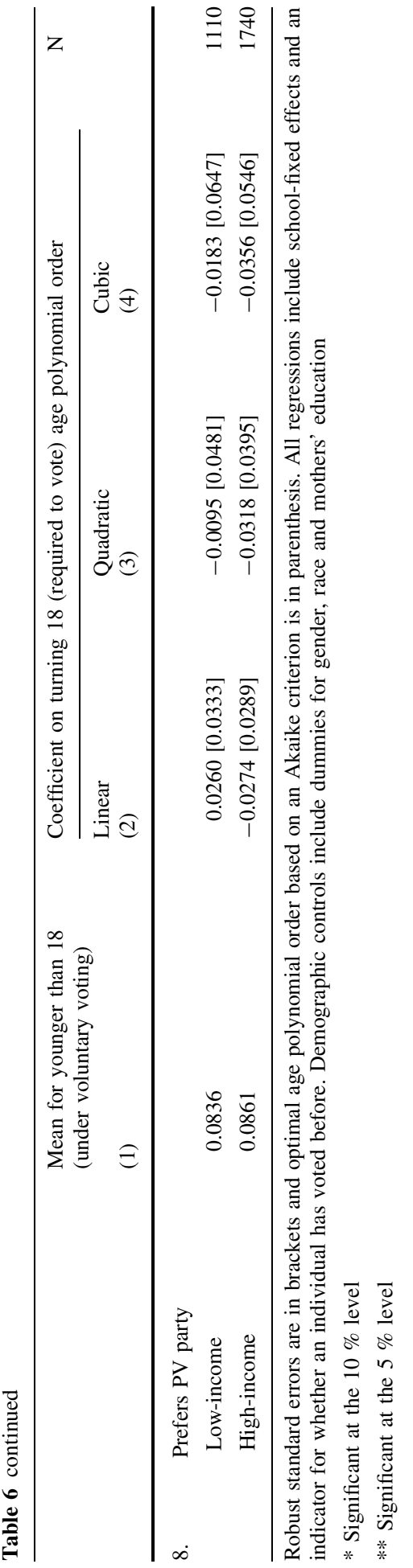




\section{References}

Aldashev, G. (2015). Voter turnout and political rents. Journal of Public Economic Theory, 17(4), 528-552.

Borgers, T. (2004). Costly voting. American Economic Review, 94(1), 57-66.

Brennan, J. (2011). The Ethics of Voting. Princeton, NJ: Princeton University Press.

Brunell, T. L., \& DiNardo, J. (2004). A propensity score reweighting approach to estimating the partisan effects of full turnout in American Presidential Elections. Political Analysis, 12, 28-45.

Carreirao, Y. S. (2006). Ideologia e partidos políticos: um estudo sobre coligações em Santa Catarina. Opiniao Publica, 12(1), 136-163.

Citrin, J., Schickler, E., \& Sides, J. (2003). What if everyone voted? Simulating the impact of increased turnout in senate elections. American Journal of Political Science, 47(1), 75-90.

Coate, S., \& Conlin, M. (2004). A group rule-utilitarian approach to voter turnout: Theory and evidence. American Economic Review, 94(5), 1476-1504.

Degan, A. (2006). Policy positions, information acquisition and turnout. The Scandinavian Journal of Economics, 108(4), 669-682.

Downs, A. (1957). An Economic Theory of Democracy. New York: Harper and Row.

Franklin, M. (2004). Voter Turnout and the Dynamics of Electoral Competition in Established Democracies since 1945. Cambridge: Cambridge University Press.

Frota, M. (2014). Partidos investem em celebridades e políticos experientes para crescer na Câmara. Portal IG in http://ultimosegundo.ig.com.br/politica/2014-02-18/partidos-investem-em-celebridades-epoliticos-experientes-para-crescer-na-camara.html

Funk, P. (2010). Social incentives and voter turnout: Evidence from the Swiss mail ballot system. Journal of the European Economic Association, 8, 1077-1103.

Gerber, A., Huber, G., \& Washington, E. (2010). Party affiliation, partisanship, and political beliefs: A field experiment. American Political Science Review, 104(4), 720-744.

Ghosal, S., \& Lockwood, B. (2009). Costly voting when both information and preferences differ: Is turnout too high or too low? Social Choice and Welfare, 33, 25-50.

Godefroy, R., \& Henry, E. (2013). Voter turnout and fiscal policy. University of Montreal, Mimeo.

Gomez, B., Hansford, T. G., \& Krause, G. A. (2007). The republicans should pray for rain: Weather, turnout, and voting in U.S. Presidential Elections. The Journal of Politics, 69(3), 649-663.

Hansford, T., \& Gomez, B. (2010). Estimating the electoral effects of voter turnout. American Political Science Review, 104(2), 268-288.

Highton, B., \& Wolfinger, R. E. (2001). The political implications of higher turnout. British Journal of Political Science, 31(1), 179-223.

Hodler, R., Luechinger, S., \& Stutzer, A. (2015). The effects of voting costs on the democratic process and public finances. American Economic Journal: Economic Policy, 7(1), 141-171.

Huber, G., \& Arceneaux, K. (2007). Identifying the persuasive effects of presidential advertising. American Journal of Political Science, 51, 957-977.

Krasa, S., \& Polborn, M. (2009). Is mandatory voting better than voluntary voting. Games and Economic Behavior, 66(1), 275-291.

Krishna, V., \& Morgan, J. (2011). Overcoming ideological bias in elections. Journal of Political Economy, 119(2), 183-211.

Lee, D., \& Lemieux, T. (2010). Regression discontinuity designs in economics. Journal of Economic Literature, 48(2), 281-355.

León, G. (2015). Turnout, political preferences and information: Experimental evidence from Perú. Bureau for Research and Economic Analysis of Development (BREAD) Working Paper No. 376.

Leon, F. L. L., \& Rizzi, R. (2014). A test for the rational ignorance hypothesis: Evidence from a natural experiment in Brazil. American Economic Journal: Economic Policy, 6(4), 380-398.

Lijphart, A. (1997). Unequal participation: Democracy's unresolved dilemma. American Political Science Review, 91(1), 1-14.

Loewen, P., Milner, H., \& Hicks, B. (2008). Does compulsory voting lead to more informed and engaged individuals? An experimental test. Canadian Journal of Political Science, 41, 655-672.

Martinez, M. D., \& Gill, J. (2005). The effects of turnout on partisan outcomes in U.S. Presidential Elections 1960-2000. The Journal of Politics, 67(4), 1248-1274.

Matsusaka, J. G. (1995). Explaining voter turnout patterns: An information theory. Public Choice, 84, 91-117.

Meredith, M. (2009). Persistence in political participation. Quarterly Journal of Political Science, 4(3), 186-208.

Mullainathan, S., \& Washington, E. (2009). Sticking with your vote: Cognitive dissonance and political attitudes. American Economic Journal: Applied Economics, 1(1), 86-111. 
Prior, M. (2010). You've either got it or you don't? The stability of political interest over the life cycle. The Journal of Politics, 72, 747-766.

Sears, D. O., \& Funk, C. L. (1999). Evidence of the long-term persistence of adults' political predispositions. The Journal of Politics, 61, 1-28. 